\title{
COMBINATION OF WOBBLE BOARD AND CORE STABILITY EXERCISE MORE IMPROVES BODY BALANCE
}

\author{
Bagas Anjasmara ${ }^{1 *}$, Ketut Tirtayasa ${ }^{2}$, Wahyuddin $^{3}$, Nyoman Adiputra $^{2}$, Gusti Widianti $^{4}$, \\ Dewa Primayanti ${ }^{2}$ \\ ${ }^{1}$ Sports Physiology Magister Program, Faculty of Medicine , Universitas Udayana, 80234, Denpasar, Indonesia \\ 2,Department of Physiology, Faculty of Medicine, Universitas Udayana, 80234, Denpasar. \\ ${ }^{3}$ Faculty of Physiotherapy, Universitas Esa Unggul, 11510, West Jakarta, Indonesia \\ ${ }^{4}$ Department of Anatomy, Faculty of Medicine, Universitas Udayana, 80234, Denpasar. \\ Bagasanjamara2013@gmail.com
}

\begin{abstract}
Introduction: Lack of physical activities or a sedentary lifestyle will affect body balance and the increased possibility of injury. Improving body balance can be done by training muscles that have a function to maintain the balance. This study aims to identify the combination of wobble board exercise and core stability exercise is better compared to calf raise exercise and core stability exercise in improving body balance of students with love physical activities. Methods: This research used experimental methods pre and post-test two-group design with. The experimental group was given a wobble board and core stability exercise, while the control group was given calf raise and core stability exercise. The number of samples in each group is 18 people and each of the groups was given 3 times in a week of exercise for 6 weeks. The balance measurement in this study used a standing stork test. Result: The research result is the body balance Experimental Group is increase with mean pre-test score is $10,80 \pm 4,64$ seconds becomes $26,51 \pm 5,41$ seconds during the post-test, and $p=0,001$. In the Control Group, there is an increased body balance with mean pre-test 8,39 $\pm 4,51$ becomes $20,54 \pm 5,18$ during the post-test and $p=0,001$. There is a significant difference in the increase of body balance in the Experimental Group and Control Group with $p=0,002(p<0,05)$. Conclusion: The combination of a wobble board and core stability exercise is better than the combination of calf raise and core stability exercise in improving body balance.
\end{abstract}

Keywords: Body Balance; Low Physical Activities; Wobble Board Exercise; Calf Raise Exercise; Core Stability Exercise

\section{INTRODUCTION}

The world continues to progress from time to time and brings various forms of progress or development to help and facilitate humans. From the positive effects, many activities are shortened and simplified, while the negative effect is that people become lazy to move. In daily activities, students are busy with various college activities. This behavior is called as sedentary, which is a relaxed behavior such as sitting down, laying, and other daily activities in working place (work in front of a computer, read and others), and at home ${ }^{1}$.

The problem that arises nowadays is the lazy habit to do physical activities, because of the environment which facilitates and simplifies the activities. It affects the decrease in health components in the body and one of them is to maintain body balance. Balance is an ability to do relaxation towards body position, so the body remains stable. Body disorders that effect on someone who is easily injured will cause a decrease in productivity ${ }^{2}$.

Core stability exercise is a concept of exercise to train stabilized muscles in the trunk, pelvis, and lower limb ${ }^{3}$. Other exercises that are often used to train balance are exercise with a wobble board. The principle of this exercise is to improve body balance control function that is a sensory information system, central processing, and effector to be able to adapt through environmental changes and retraining proprioseptive ${ }^{4}$.

Other exercises to improve balance is calf raise. The purpose of this exercise is to create lengthening in the achilles tendon or calf muscle to release abnormal crosslinks, so the decreased ankle 
stabilization can increase. Ankle flexibility is generally weaker and its flexibility is decreased due to chronic ankle sprain or lack of physical activities. By performing calf raises exercise can help to retrain balance ${ }^{5}$.

Based on the description of problems and three exercises above, the researcher is solicitous to combine core stability exercise with two kinds of exercise to lower limb which each its advantages and mechanisms. This study aims to investigate the combination of a wobble board and core stability exercise that improves more body balance compared to the combination of calf raise and core stability exercise of students with low physical activity.

\section{METHODS}

a. Methodology

\section{Study Design}

The research design is true experimental with pre-post test control group design. The research subject is students of Health Polytechnic of the Ministry of Health Makassar, Department of Physiotherapy with low physical activities, and low score in body balance.

\section{Subjects Recruitment}

The sampling technique is using purposive sampling that used the inclusion and exclusion criteria of the sample. After obtaining the amount of sample needed is 32 , then it is divided into two groups with the random allocation that is an experimental group and control group, where each consists of 18 people. This study has been approved by the health research ethics committee health polytechnic Makassar.

\section{b. Material and Procedure}

The research procedure is started with a literature study that is relevant to the research topic, after that is decided and conducted permission process in the place will be used to do the study, prepare standard measurement tools with accuracy which can be trusted and scientifically recognized. Before choosing the sample, the process of the study is explained to the respondents and followed by asking permission to be the sample of this study.

The sample has passed the process of inclusion and exclusion criteria, then divided into 2 groups and given the combination of exercises that have been decided. The experimental group was given a wobble board and core stability exercise, on the other hand, the control group was given calf raise and core stability exercise. The study is conducted with a frequency of 3 times a week for 6 weeks. The instrument used are wobble board, informed consent, stopwatch, weight and height measurement tool, and international physical activity questionnaire (IPAQ) form.

\section{c. Assessment}

Physical activity measurement in this study is using IPAQ that is a questionnaire that assesses the level of a person's physical activity. Body balance measurements are using a standing stork test, a balance measurement which is done by standing with one led and tiptoe, the position of arms are on the hips. The measurement and data collection of body balance is conducted before the intervention and after 6 weeks of intervention

d. Data Analysis

Descriptive analysis is used as data analysis to present the characteristics of the research subject which includes age, body mass index, and body balance. Shapiro Wilk test is used as a normality data test and the Lavene test is used as a homogeneity test. The Paired-sample t-test is used as a hypothesis test to identify the increased balance score of the experimental group and control group and to compare the result of the increased score by using independent-samples t-test. 
RESULT

1. The Characteristics of Research Subject

Table 1. The characteristics of the research subject

\begin{tabular}{cccc}
\hline Characteristics of the subject & $\begin{array}{c}\text { Experimental } \\
\text { Group } \\
\text { Mean } \pm \text { SD }\end{array}$ & $\begin{array}{c}\text { Control Groups } \\
\text { Mean } \pm \text { SD }\end{array}$ & $\begin{array}{c}\text { p- } \\
\text { value }\end{array}$ \\
Age (Year) & $20,28 \pm 0,89$ & $20,06 \pm 0,93$ & 0,472 \\
physical activities (Mets/week) & $545,06 \pm 36,04$ & $536,06 \pm 38,59$ & 0,738 \\
Body mass index (kg/m²) & $21,28 \pm 1,24$ & $21,44 \pm 1,51$ & 0,475 \\
Body Ballance: & $10,80 \pm 4,64$ & $8,39 \pm 4,51$ & 0,124 \\
Pre-test (second) & $26,51 \pm 5,41$ & $20,54 \pm 5,18$ & 0,002 \\
Post-test (second) & $15,71 \pm 3,10$ & $12,15 \pm 2,10$ & \\
\hline Difference (second) & & &
\end{tabular}

The characteristics are in a form of the physical condition of the subject in this study such as age, body mass index, and the comparison of balance before and after the intervention.

\section{Normality test and data homogeneity}

Table 2. Normality test and data homogeneity

\begin{tabular}{cccc}
\hline \multirow{2}{*}{ Body balance } & \multicolumn{2}{c}{ Normality $^{1}$} & \multirow{2}{*}{ Homogenity $^{2}$} \\
\cline { 2 - 3 } & Experimental Group & Control Groups & 0,819 \\
Pre-test & 0,260 & 0,060 & 0,830 \\
Post-test & 0,091 & 0,608 & 0,227 \\
Difference & 0,976 & 0,779 & \\
\hline
\end{tabular}

${ }^{1}$ Saphiro Wilk Test

${ }^{2}$ Lavene tests

After the normality test is conducted by using the Shapiro Wilk test and the homogeneity test by using Lavene tests the score is obtained > 0,05 for pre-test, post-test, and the difference of the increased balance. It means that the data distribution is normal and homogeneous.

\section{Balance improvement test in Experimental Group}

Table 3. Balance improvement test in Experimental Group

\begin{tabular}{cccc}
\hline $\begin{array}{c}\text { Experimental Group body } \\
\text { balance }\end{array}$ & $\mathrm{N}$ & Mean \pm SD & P-Value \\
\hline Pre-test & 18 & $10,80 \pm 4,64$ & 0,001 \\
Post-test & 18 & $26,51 \pm 5,41$ & \\
\hline Paired-sample t-test. & & &
\end{tabular}


In table 3, shows the increase of mean balance of the Experimental Group which is measured by using a standing stork test.

\section{Balance improvement test in Control Group}

Table 4.Balance improvement test in Control Group

\begin{tabular}{cccc}
\hline Control Groups body balance & N & Mean \pm SD & P-Value \\
\hline Pre-test & 18 & $8,39 \pm 4,51$ & 0,001 \\
Post-test & 18 & $20,54 \pm 5,18$ & \\
\hline
\end{tabular}

Paired-sample t-test.

In table 4, there is an increase in the mean balance of Control Group which is measured by using a standing stork test

\section{The comparison of pre-test of Experimental and Control Groups}

Table 5. The comparison of pre-test of Experimental and Control Groups

\begin{tabular}{lcc}
\hline \multicolumn{1}{c}{ Pre-test body balance } & Mean \pm SD & p-value \\
\hline Pre-test Experimental Group & $10,80 \pm 4,64$ & 0,124 \\
Pre-test Control Groups & $8,39 \pm 4,51$ & \\
\hline
\end{tabular}

Independent-samples t-test.

Table 5 shows the comparison of mean pre-test in both groups by using independent-samples t-test. It is obtained p-value $>0,05$ which means that this study used homogeneous data at the beginning of the study. To identify the effectiveness difference in both combinations of exercise towards body balance improvement in the Experimental Group and Control Group, statistic analysis is used with independent-samples t-test by comparing the result of the post-test in both groups.

\section{Differential test in improving balance of Experimental and Control Groups}

Table 6. differential test in improving the balance of Experimental and Control groups

\begin{tabular}{cccc}
\hline & N & Mean \pm SD & p-value \\
\hline Post-test Experimental Group & 18 & $26,51 \pm 5,41$ & 0,002 \\
Post-test Control Groups & 18 & $20,54 \pm 5,18$ & \\
\hline
\end{tabular}

Independent-samples t-test.

Table 6 shows the mean post-test of the Experimental Group which was given the combination of core stability and wobble board exercise that is $26,51 \pm 5,41$ seconds and the mean post-test of the 
Control Group which was given the combination of core stability and calf raises exercise is $20,54 \pm 5,18$ seconds.

From the independent-samples t-test, it was obtained the $\mathrm{p}$-value $=0,002$. This indicated that there is a significant difference in body balance improvement in both groups. If it is observed form the mean score, the Experimental Group is higher than the Control Group which is given the combination of core stability and calf raises exercise.

\section{DISCUSSION}

\section{The Effect of the Combination of Wobble Board Exercise and Core Stability Exercise in Improving Body Balance of Students with Low Physical Activities}

In theory, combining wobble board exercise and core stability exercise gives an effect on the response of movement direction. These muscles give dynamic support to a spine segment to help in maintaining a stable position, so stress on the limited motion has not occurred. Both global muscles and core muscles have a function to stabilize in providing multi-segment stabilization of the spine. It shows that only posture stability (activation of core stability muscles) is optimal, then mobility in the extremities can be performed efficiently ${ }^{6}$.

The exercise by using a wobble board can stimulate mechanoreceptors to activate joint sense or feeling in the joints. During training/exercise, the intrafusal and extrafusal fibers will continue to receive sensory input which will be transferred and processed in the brain so that those can determine the amount of contraction needed. Half of the responses will be transferred back to extrafusal and activate the Golgi tendon so that coordination will have occurred.

The previous research which was conducted in 2014 and states that the addition of core stability exercise to balance board exercise 3 times a week for 4 weeks, improves more balance compared to given balance board exercise only ${ }^{7}$. Two studies in 2019 state that core stability dan balance board exercise is effective in decreasing the risks of falling and increasing balance in healthy young adults and decreasing risks of injury in athletes. The exercise by using a wobble board 4 times a week for 4 weeks is effective to increase dynamic and static balnce ${ }^{8}$. The surface of the wobble board will cause an inconsistent stimulation as the effect of the unstable surface to receive by muscles and joints which has a rapid effect on sensory information retrieval and more efficiently captured by the central nervous system. Sensory input only comes from visual, vestibular, and somatosensory (tactile and proprioceptive) ${ }^{8,9}$.

\section{The Effect of Combination of Calf Raise Exercise and Core Stability Exercise in Improving Body Balance of Students with Low Physical Activity}

In theory, core stability exercise has a similar effect if it is combined with calf raise exercise which is included in close kinetic chain exercise (CKC), where the exercise is used to improve ankle stability. This exercise is using the load within the body itself by maximizing the strength of the muscles and there will be an increase in muscle strength to stimulate mechanoreceptors around the joint. Therefore, it stimulates muscle contraction, muscles strengthen, improve joint stability, and balance in the functional body when performing various movements.

This exercise to stretch the Achilles tendon or calf muscle, so that ankle stabilization and proprioceptive will improve. Calf raise exercise will restores ankle joint motion and improve muscle flexibility, improve muscle strength and endurance and improve ankle stability, and ankle will be more stable and prevent injuries. Calf raise exercise can improve maximum muscle contraction and support increased ankle functional stability. It is following the previous study conducted in 2017 that providing a combination of core stability exercise and calf raise exercise or heel raise exercise 12 times for 4 weeks can improve static balance ${ }^{10}$.

The Combination of Wobble Board Exercise and Core Stability Exercise Improve More Body Balance Compared To the Combination of Calf Raise Exercise and Core Stability Exercise

Core stability exercise is an exercise that generally has a purpose to form or strengthen the muscles, especially muscles around the back and hip, in which those muscles have important roles to maintain balance in the human body. The dynamic function of core muscle is to maintain body balance 
while moving. Before a person does a movement, creating body balance is first done to move other body parts functionally.

By adding wobble board exercise in core stability exercise gives an effect to improve body balance, where lower limbs can maintain body balance and adjust body portions in various movements. Body balance in every position can be only performed if the stability muscles in the legs work together in response to changes in position, fulcrum, gravitational force, and body alignment. Simultaneous muscle work in wobble board exercise produces a proper response in terms of strength and speed reaction of muscles to other muscles in performing certain motion functions, wherein this exercise there must be good coordination between the vestibular system, the proprioceptive, and the musculoskeletal system.

The additional calf raise which is strengthening in core stability will improve static balance where regular tiptoe can make contraction in the gastrocnemius and plantaris muscles, and with this contraction muscle strength will improve. Khalaj et al, in their study, states that the decrease of legs muscle strength will affect to the ability in maintaining a good balance to a person with injuries or a healthy person with no injuries, therefore strengthening is important to be considered in rehabilitation and preventing injuries due to strengthening exercise will improve the work of muscles. It will impact the improvement of strength in connective tissues such as tendons, ligaments, and intramuscular and there is a possibility for an increase in body balance as well as positive changes in body composition, improve physical performance in everyday life ${ }^{11}$.

The result in this study states that the combination of wobble board exercise and core stability exercise improves more body balance in students with low physical activities compared to the combination of calf raise exercise and core stability exercise. It is along with the previous study conducted by Ha et al, that by giving regular exercise in the form of a method to increase the muscle strength of lower limbs which is applied to the control group, it is obtained that there is an effect to the increase of balance, especially in chronic ankle sprain condition, however, the treatment in this study is conducted in uneven wobble board similar with the one which is applied to the experimental group in that study, shows a significant increase of balance ${ }^{11,12}$.

This is happened due to an unstable ankle, which is also caused by the weak muscles and deficit proprioceptive. To improve proprioceptive, balance exercise is needed through the unstable supporting surface so there are optimal synergistic responses, and muscle strength to maintain balance can be better ${ }^{12}$.

The previous study done in 2013 states that a person stands in an unbalanced surface like a wobble board, that person will try to keep the body upright to reduce the instability which is caused by the wobble board, so that person activated core vertebra and pelvic muscles so there will be more sustainable of core stability exercise in maintaining balance in both static and dynamic form ${ }^{13}$.

Providing strengthening exercise can be considered because strengthening exercise is important in improving muscles performance resulting in increased strength in connective tissue such as tendons, ligaments, and intramuscular connective tissue and it is possible to improve body balance, so that there is positive body composition and improve physical performance in daily life $\mathrm{e}^{11,12}$.

\section{CONCLUSION}

1. The combination of wobble board exercise and core stability exercise can improve the body balance of the students with low physical activities.

2. The combination calf raises exercise and core stability exercise can improve the body balance of the students with low physical activities.

3. The combination of wobble board exercise and core stability exercise improves more body balance compared to the combination of calf raise exercise and core stability exercise in students with low physical activities.

\section{CONFLICT OF INTEREST}

The authors declare no conflict of interest

\section{ACKNOWLEDGEMENT}


The researcher would like to send gratitude to both my beloved parents Masdin, S. Sos, M.Si and Dwi Juni Haryanti who always give support morally and financially, my siblings Widya Lukitasar and Queensa Zahira who always remind me to finish this study on time, and friends who always give support and encouragement during this study. Moreover, I'll like to convey my gratitude to all the research subjects, the students of Physiotherapy Health Polytechnic of the Ministry of Health Makassar, who happily always take the time to participate in this research, so that has been given a chance and time to finish this study.

\section{REFERENCES}

1. Candrawati S. Hubungan Tingkat Aktivitas Fisik Dengan Indeks Massa Tubuh (IMT) dan Lingkar Pinggang Mahasiswa. Soedirman Journal Nursing. 2011;6(2):112-118.

2. Nala IG Ngurah. Principles of Sports Physical Training. Denpasar: Udayana University; 2015.

3. Zulvikar J. Pengaruh Latihan Core Stability Statis (Plank Dan Side Plank) dan Core Stability Dinamis (Side Lying Hip Abduction Dan Oblique Crunch) Terhadap Keseimbangan. Journal Phyisical Education Healt Sport. 2016;3(2):96-103.

4. Anggita MY, Ramadani FS. Perbedaan Intervensi Wobble Board Exercise Dengan 4 Single Limb Hopping Exercise Untuk Meningkatkan Stabilitas Ankle pada Kasus Sprain Ankle Kronik. Jurnal Fisioterapi. 2018;18(1):33-41.

5. Gunarto W, Winaya IMN, Griadhi IPA, Adiputra LMISH. Perbedaan Pemberian Latihan Squat Dengan Calf Raises Pada Intervensi Plyometric Jump To Box Terhadap Peningkatan Daya Ledak Ekstremitas Bawah Ekstrakurikuler Basket Sma di Denpasar. Majalah Ilmiah Fisioterapi Indonesia. 2019;7(2):9-13.

6. Bagherian S, Ghasempoor K, Rahnama N, Wikstrom EA. The effect of core stability training on functional movement patterns in college athletes. Jurnal Sport $n$ Rehabilitation. 2019;28(5):444-449. DOI:10.1123/jsr.2017-0107

7. Laksono A, Adiputra N, Sugijanto. Pelatihan Core Stability dan Balance Board Exercise Lebih Baik Dalam Meningkatkan Keseimbangan Dibandingkan Dengan Balance Board Exercise pada Mahasiswa Usia 18 - 24 Tahun Dengan Kurang Aktivitas Fisik. Sport Fitnes Journal. 2014;2(1):134 - 149.

8. Ismail Marzuki, Soemardiawan. Pengaruh Latihan Core Stability Statis (Plank And Sideplank) Terhadap Keseimbangan Tubuh pada Pemain Ps Ikip Mataram Tahun 2019. Jurnal Ilmu Sosial dan Pendidikan. 2019;3(2):400-408. http://ejournal.mandalanursa.org/index.php/JISIP/index.

9. Sundarganesh, Mohandas, Kiribukaran V. Effect of Wobble Board Balance Training Program among Athletes with Functionally Unstable Ankle Joint. Medical Health (University Kebangsaan Malaysia). 2015;10(1):17-22.

http://search.ebscohost.com/login.aspx?direct=true\&db=c8h\&AN=117754994\&amp\%0Alang=ptbr\&site=ehost-live.

10. Witayanti MRC, Andayani NLN, Tianing NW. Pemberian Core Stability Exercise Kombinasi Heel Raises Exercise Sama Baik Dengan Core Stability Exercise Kombinasi Ankle Strategy Exercise Terhadap Keseimbangan Statis Anak Flat Foot Usia 9-11 Tahun Di Sekolah Dasar Negeri 4 Tonja Denpasar. Majalah Ilmiah Fisioterapi Indonesia. 2017;5(3):31-34.

11. Khalaj N, Vicenzino B, Heales LJ, Smith MD. Is Chronic Ankle Instability Associated With Impaired Muscle Strength? Ankle, Knee, and Hip Muscle Strength In Individuals With Chronic Ankle Instability: A Systematic Review With Meta-Analysis. British Journal of Sports Medicine. 2019:1-9. DOI:10.1136/bjsports-2018-100070

12. Ha S-Y, Han J-H, Sung Y-H. Effects of Ankle Strengthening Exercise Program on An Unstable Supporting Surface on Proprioception and Balance In Adults With Functional Ankle Instability. Journal of Exercise Rehabilitation. 2018;14(2):301-305. https://doi.org/10.12965/jer.1836082.041.

13. Larcom A. The Effects of Balance Training on Dynamic Balance Capabilities in the Elite Australian Rules Footballer. 2013. Thesis Presented to the School of Sport and Exercise Science. Victoria University. 